REVIEWING ELEMENTS OF FEMINISM IN A MALAYSIAN PLAY: KUALA LUMPUR KNOCK-OUT

\author{
Ahmad Kamal Basyah Sallehuddin \\ Universiti Malaysia Sarawak
}

\section{Rosdeen Suboh}

Cultural Centre, University of Malaya

Corresponding Author kudin@um.edu.my
Kuala Lumpur Knock-Out (henceforth to be known as " $K L-K O$ ") is the second project of Kuali Works. $K L-$ $K O$ is the most commercial performance staged by Kuali Works; this was the first time Kuali Works advertised its play in mainstream newspapers in the, as well as solid patronages from an impressive list of sponsors. Written and directed by Ann Lee, it was staged in Experimental Theatre, Kuala Lumpur in 1996. KL-KO revolves around the life of Tan Ai Leng (played by critically acclaimed dancer Mew Chang Tsing), a young Chinese woman from Penang who dreams of fighting Mike Tyson in an exhibitionboxing match in Kuala Lumpur. Simultaneously, her best friend Mazuri experience a rather unpleasant incident at her workplace. After 22 years, it is recompensing to look back at the relevance of the issues highlighted in this play. Simultaneously, one would realise that the elements of feminism discussed in this play are the real problems faced by women in this country, even after the new millennium.

Keywords: feminism, detractors, sexual harassment, matriarch, patriarchy 


\section{INTRODUCTION}

Kuali Works Sendirian Berhad is one of the three flagship brands of The Kuali Group, Malaysia's first all-women arts company. Co-founded in 1994, its main activities linger around theatre, television and publications. 'Kuali' ("wok" in English) is selected as a fitting metaphor for the company's ability to bring together women from all over the place to create 'food for thought' to cater to theatre enthusiasts. According to Ann Lee, one of the co-founders, Kuali Works offers a completely different experience to Malaysian theatregoers, as its works focuses on women issues, which was considered rare in the Malaysian performing arts scene in the early 1990s (A. Lee, personal communication, May 31, 2018). Highlighting women issues in a performance is strongly related to the feminist theatre and its practitioners. According to a renowned feminist theatre practitioner, Helene Keyssar (1984), feminist writing must be done by feminists or female playwrights, in order to justify that feminist drama is about female issues and agendas written exclusively by women. Charlotte Canning (1996) identified two primary sets of performers within the feminist theatre groups: those already involved or working in the theatre who sought alternative channel for their artistry and those not previously working in the area but found theatre as "a locus for political agency". In 1999, Elaine Aston introduces her concept of feminist theatre practices, focusing on three different schools of feminism: liberal feminism, cultural feminism and socialist feminism. This paper is focusing only on liberal feminism and cultural feminism. The political aim in a liberal feminist performance is to increase opportunities for women in society, while the characters should include strong roles for women often represented within domestic and familial spheres. As for cultural feminism, the political aim is to contest the patriarchal organisation of society, while the characters should indicate 'Woman' as 'Other', as well as highlighting intrafeminine relationship with emphasis on mother/daughter relation.

Kuala Lumpur Knock-Out (henceforth to be referred to as $K L-K O$ ) is the second project of Kuali Works. Written and directed by Ann Lee, it was staged in Experimental Theatre, Kuala Lumpur in 1996. KL-KO revolves around the life of Tan Ai Leng (played by critically acclaimed dancer Mew Chang Tsing), a young Chinese woman from Penang who dreams of fighting Mike Tyson in an exhibition-boxing match in Kuala Lumpur. Ai Leng has a close friend, Mazuri (played by Faridah Abdullah), and together they work in an electronic factory. Since announcing her so-called ambitious intention, Ai Leng receives more discouragement than moral support she truly deserves, except from Mazuri. Things take a sour turn when "someone" at the factory where both of them are working sexually harasses Mazuri, and since the offender is a relatively "important" figure in the organization, no charges are pressed against him. 
This incident burns the desire of Ai Leng to stand up and challenge Tyson; she gets her opportunity after successfully persuading the organizer(s) that "she is a good commercial prospect" (Lee, 1996). In the end, Ai Leng confronts her truly eccentric opponent and knocks him out in the cold. The aforesaid play was and still is the most commercial performance ever staged by Kuali Works as this was the first time Kuali Works advertised its play in mainstream newspapers in the country, as well as strong patronages from an impressive list of sponsors, including SBB Unit Trust Management Berhad and Andersen Consulting. In addition to Mew Chang Tsing and Faridah Abdullah, the play also featured Mahadzir Lokman, Chris $\mathrm{Ng}$, Vicky Ho, Mehran Salleh, Ako Mustapha and Kudsia Kahar. In a true Malaysian spirit, the play blended three major languages in Malaysia - Malay, English and Cantonese, a Chinese dialect. Now, after 22 years, it is recompensing to look back at the relevance of the issues highlighted in this play. Simultaneously, one would realise that the elements of feminism discussed in this play are the real problems faced by women in this country, even after the new millennium.

\section{WOMEN AND DEFYING DETRACTORS}

$K L-K O$ is a lightweight, humorous feminist play with serious issues revolving from all walks of life in Malaysia. Featuring a mixture of liberal feminism and cultural feminism, the play also satirised traditional sex roles and portrayed oppressive situation simultaneously. The insertion of boxing in this play represents an essential form of liberal feminism; boxing is a sportsmanship where fighting is crucial to achieve victory; the ring is a space where one has to defy his/her opponent in order to make his/her presence recognized and be taken into account. Ann Lee justifies her own agenda of feminism when the would-be opponent of Mike Tyson is Tan Ai Leng, a Muhammad Ali worshipper who is just like a typical girl-next-door - bright, witty, naïve, honest, appealing. In addition, she also has a strong no-nonsense persona that helps her to win over the event organizers and later the audience. The play has strong roles for women within domestic and familial spheres, thus making it a liberal feminist performance. It is vital to mention that $K L-K O$ has the influence of another feminist theory; cultural feminism exists as the play also centres on intra-feminine element, which emphasises on woman-to-woman relations.

Lee creates characters that contribute to the many elements of feminism in the play. First, there is Tan Ai Leng, the 26-year-old girl-next-door who has a dream that is larger than life. As a Malaysian young woman who lives in a developing territory, $\mathrm{Ai}$ Leng is expected to be sweet, feminine and graceful - which is true, since Ai Leng has all the listed characteristics. However, she also has a challenger spirit in her that 
only her best friend Mazuri understands and supports (besides lukewarm advocacy from Nenek, Mazuri's grandmother and Pa, Ai Leng's father). In the play, Ai Leng, who is an ardent admirer of boxer Muhammad 'The Greatest' Ali (there are scenes where she faithfully recites Ali's past victories), decides to take up a challenge that women would definitely avoid: confronting Mike Tyson in a boxing match. Her determination for approval at the beginning of the play is not only funny, but makes the audience realise that Ai Leng's ambition is the foundation of the play. In other words, the character Tan Ai Leng is a symbol of liberal feminism - she blurs the thin line between masculinity and femininity. Gayle Austin (1990) contends that liberal feminist theory aims to minimise differences between men and women. Through theatre, liberal feminists would promote identities of women, increase awareness of feminist issues and advocate corrective change.

Looking from the liberal's aspect, Ai Leng's dream, which is to confront Mike Tyson in a boxing championship, also represents the idea of individual dignity that seeks her right to self-fulfilment, as opined by Patti Gillespie (1978). A liberalised female character is free to decide, take action, attack contemporary practices and ignore any sort of renunciation or retribution from the audience towards her personally. The attack, while using highly critical words, is more pacified as compared to confrontational violence in a conflict between men, or between radical feminists and their nemesis. Her enthusiasm over her ambition can be witnessed in the opening scene, when she sanguinely auditions for Mahadzir Lokman and his associate Frank. As Mahadzir acknowledges that her name is not on the preliminary list, Ai Leng introduces herself and assures Mahadzir and Frank by saying "I know you are looking for people, very good people, which is why I am here. I know I am a girl, but you don't let that worry you ok? I can box." (Lee, 1996, p. 2). When Frank tries to explain that they are specifically looking for a male candidate by calling her "sweetie", Ai Leng responds by saying "Tan Ai Leng, that's my name. But you can change it if you like. My family will be happy. They don't know I'm here." (Lee, 1996, p. 2); courageously, Ai Leng 'silently thumps' Frank's typical male attitude in addressing a female stranger by mentioning her name in full, which just shows that she has autonomy and dignity, and not to be banal in addressing her.

Ai Leng also reinforces a positive self-image for being a woman, which is also another aspect of liberal feminism (Aston, 1999, p. 126). First, she has a job, which exhibits that she is an independent person, even though she still lives with her parents. The latter situation is more customary in this part of the world where single, unmarried daughters (with or without careers) are expected to live in the same house as their 
parents. Second, Ai Leng shows that being a blue-collar employee does not mean she has to be ignorant of knowledge. Throughout the play, she shows how much she knows and learns about her idol, Muhammad Ali a.k.a. Cassius Clay, as well as some trivia regarding boxing. Ai Leng shows that one must embark upon a beloved subject seriously.

Subsequently, she does not turn herself into a ferocious female character even though she is all for challenging Mike Tyson; in person, Ai Leng is still a graceful feminine just like her compatriots, where she still respects and obeys the elders, at the same time as when she is struggling to let her intentions be accepted by her parents, Pak Cik and Nenek. She also shows that she is a worthy daughter to her parents and a loyal friend to Mazuri, especially in the latter's time of need. The audience witness her exchange of demeanours throughout the whole play without any sense of grandiloquence - a feminine factory girl transforming into an allay boxer while training for her upcoming match. Using her own feminine charms, she persuades Mahadzir Lokman to reconsider her ambition efficaciously in a passionate letter. In the end, Ai Leng is finally accepted to fight Mike Tyson once the organisers believed that she is eligible for commercial appeal, or which Lee recognises as "capital profiteering" (A. Lee, personal communication, May 31, 2018); a female boxer is viewed as "family-friendly", thus more families will buy tickets and watch the competition. However, Mahadzir reminds his colleague Frank to be cautious as "I don't want any accusations of exploitation. So we keep a tight rein on publicity and interviews." (Lee, 1996, p. 45). Both men acknowledge that Ai Leng may be exploited as "the main event", but they are wary not to be caught utilising this potential for fear of retaliation. This can be seen as another triumphant for Ai Leng in controlling her detractors; while she has offered herself as the main attraction, her appeal to the public is within her control and men will not use her image at their own free will. For the record, Mike Tyson was accused and later imprisoned for raping Miss Black America 1991, Desiree Washington in 1992; the will to defeat Tyson can be seen as a symbol of defeating sexual predator and aggressor.

\section{ADDRESSING SEXUAL HARASSMENT}

Another significant character from $K L-K O$ is Mazuri. In general, Mazuri is also an independent person who works at the same factory with Ai Leng, and a fighter in her own league. However, while Ai Leng's fight deals with her righteous ambition, Mazuri's personal battle is more personal, yet despicable. Mazuri represents another sect of women labelled "victims" in their daily lives. Charlotte Canning (1996) believes that when issues about rape and violence emerged in a performance, some areas of these tragic experiences were profoundly and negatively imbedded; on an 
unsuspecting day, a lighting engineer at her workplace sexually harasses Mazuri, soon after the contentious night shift was implemented. Before the incident, Mazuri is optimist about the plan, and her optimism shows that she is also an individual with a positive self-image.

Even though her grandmother Nenek raises her concern over this new arrangement, Mazuri strongly feels that her safety will not be compromised as the company provides transportation to and from the factory for other female employees, and that her best friend Ai Leng is supportive and compassionate in lending her support. Nenek's anxiety about the newly-introduced night shift must have stemmed from the traditional belief that women must not stay out late at night, but Mazuri stands firm on her belief that her colleagues will be vigilant as support system. Alas, as any other unsuspecting harassment's victim, Mazuri's sincerity in contributing to her family's household leads to a traumatising experience.

After "surviving" the harassment, Mazuri also has to fight to keep her dignity alive. First, much to her horror, she deliriously has to report the incident to a male police officer, as a female one is unavailable. This is not an issue of sexism, as Mazuri prefers to speak to a policewoman, her female counterpart, as she believes the latter would be more sympathetic. Moreover, she has to explain to a total stranger that her breasts were fondled as she was leaving the restroom by "somebody important and respected" at the factory. For her ability to finish her report, Mazuri displays her position as a dignified individual, who at the same time is belligerent in seeking her justice as a victim. Of course, her report faces plenty of obstacles, as the guidelines for charging an individual for committing sexual harassment is relatively new at the time this play was written and performed, and her report has been categorised as 'insufficient evidence' as there is no eye witness whatsoever when the groping incident takes place.

Mazuri's potency in overcoming this incident is much-admired. At one point, she has to face unwanted glares from her co-workers, who assume she is partly to be blamed for the mess; in general, when a woman accuses a man for sexually harassing her, she is partly blamed for nonsensical excuses. After consulting a lawyer, who had to explain to Mazuri and her family that the absence of physical harm and insufficient evidence would do nothing to any impending lawsuit, she calmly drops her charges. Mazuri's positive attitude aligns with the reinforcement of a positive self-image even though she has just trounced her darkest days; she even hopes that the so-called 
new guidelines (which will be outlined by her supervisor, $\mathrm{Mr}$. Wu) would benefit her fellow co-workers, and females alike.

To further liberal agendas within the comedic performance, $K L-K O$ interweaves $A i$ Leng's wildest dream with a number of issues and themes involving women in general. In the play, Mazuri is sexually harassed (Lee uses the phrase "modest was outraged") by a man, who is recognized as important. Co-incidentally, in reality, a senior politician from a Southern state was alleged to have had sex with an underaged girl, who also reputedly had several sexual escapades with several men; at the end, the politician was never charged. In $K L-K O$, Mazuri is unable to seek justice, so she did just like many other women who have had similar experience - bury the evidence and move on with her life. However, her 'tragedy' seems to burn the fighter flame in Ai Leng, who finds a renewed spirit and inspiration to challenge Tyson in Kuala Lumpur. Two possible outcomes could be derived from this first situation women continue to live in denial when something bad happens (just like Mazuri) or women become stronger and try to heal the problem by looking for possibilities to turn things around. Alas, when this scene was staged in 1996, the audience was laughing hysterically the moment Mazuri revealed the most embarrassing moment in her life, instead of being sympathetic. Lee thought the timing of the scene was not right - many audience members were premature in digesting the horror of sexual harassment as they perceive the scene as a joke.

Mazuri's attempt to report the incident to the authority reveals another liberal's criticism towards the bureaucracy in this country. After being supported by her closest confidants, Mazuri makes the effort to go the nearest police station and report the incident to a very sympathetic, alas not understanding police officer. However, owing to the lack of the so-called proper guidelines in highlighting sexual harassment and proper evidential aspects, the report falls silently. All along, feminists have always complained that women could never get the right access to get their adversity heard due to bureaucratic behaviour within the security and police force. Women who have been raped, battered or insulted at times are not able seek justice, as they are either dismissed or left unheard by ignorant, sexist officers; Lee explains that she is not criticising just on blind faith or emotional baggage as this is not only happening in Malaysia but other countries around the world as well (A. Lee, personal communication, May 31, 2018). 


\section{THE ESSENCE OF MATRIARCH}

Another great element that one must not overlook from this play is the positive portrayal within a family. Capitulating cultural feminism influence to claim its share in this play, both Ai Leng and Mazuri come from strong family background where each of the respective parents or guardians, especially Ma and Nenek show unfathomable and enormous concerns. This fortifies the institution of family, which is one of the strong epitomes of Malaysian lifestyles. The role of matriarch, which has been discussed earlier in the characterisation section, proves unyielding in order to support the connotation that women offer much better nurturing and caring as compared to its counterpart (though the patriarch personages in $K L-K O$ are not minuscule in their tasks). $\mathrm{Pa}$ is the first family member to provide stanchion to Ai Leng's ambition, while Pak Cik not only offers to train Ai Leng (much later in the play, right after Mazuri's harassment episode) but also has been a stalwart guardian towards Mazuri all along.

Nenek, the grandmother of Mazuri, is an optimistic and a likeable character, due to her warmth and affection towards both Mazuri and Tan Ai Leng; her nurturing yet firm attitude supports the cultural feminists' idea that women should continue to be the invincible factor to nurture and empower their God-given, care-giving behaviour. Sally Scholz (2010) supports this notion by stating that women as caregivers in the family help to instil and facilitate more compassion to benefit every aspect of social existence. For one, Nenek openly displays her endorsement of Ai Leng's effort to take up with the Mike Tyson challenge; this is clearly shown in the scene when Ai Leng is wooing Pak Cik to help her with training, though at first she is hesitant to do so. At the same time, Nenek has been an adept protector, with help from Pak Cik, to her orphaned granddaughter Mazuri, whose parents have died in a car accident. She staunchly utilises her position as the legal guardian, especially in the aftermath of the sexual harassment episode. Even though she is only a grandmother to Mazuri, Nenek takes her responsibility seriously as a caretaker, or a nurturer, which is essential in cultural feminism.

Another character that best represents the element of cultural feminism is the anachronistic Ma, Ai Leng's mother. Ma displays a typical eastern mother who constantly guards and controls her own children like 'valuable possession'. While Ma can be churlish at times, on the surface she is only doing her duty as a parent to Ai Leng: injecting harmony and femininity into a casual everyday life. Always at loggerheads with her husband, $\mathrm{Pa}$, regarding Ai Leng's aspiration to challenge Mike Tyson in the boxing arena (in which she opposes the matter, unlike $\mathrm{Pa}$ who even makes a bet alongside his friends on Ai Leng's victory chances), Ma provides the comic relief in the play. Bawdy and brash, yet the audience and the researcher can 
relate to her typical Malaysian Chinese stereotype qualities as a powerful matriarch figure in a Malaysian family. One of the legacies left behind by the colonial period is the 'divide and rule' situation. As a result, prejudices linger around the many ethnic groups in this country.

\section{CRITICISING PATRIARCHY}

$K L-K O$ clearly deals with another problem that women have to face for centuries gender stereotyping. Many people around her do not applaud Ai Leng's dream and determination to challenge Mike Tyson. She becomes a laughing stock and is discouraged, as no one would want to entertain the notion of a sweet, naïve Ai Leng getting a chance to stand next to Mike Tyson, the heavyweight champion of the world. Ai Leng is expected to become a 'minah kilang' for life; going to Kuala Lumpur all by herself is a rebellious act to some people. Unlike any other male with huge ambition, Ai Leng did work hard to convince people that she could do anything just like her male counterparts.

Ai Leng's mother further reinforces this gender stereotype showcase - the loudmouth character one could find anywhere near him/her and is always around her husband, come what may. Given the fact that the real Mike Tyson was constantly receiving bad press during this time (mid-1990s), posing Ai Leng as his opponent would further insult the institution of masculinity and male-egocentrism. Tyson represents every idea of what a hero should be (a heavyweight champion, playboy, wealthy sportsman), but at the same time he also becomes the unofficial spokesperson of male negative qualities (ornery aggressor, wife-beater, convicted rapist). In order to wring all these oppressive qualities off women, Ai Leng represents her female colleagues to humiliate Tyson, who in turn represents the many egocentric men in the real world. When Ai Leng succeeds, she gives hope to women that they can speak up and fight against their aggressor(s) and oppressor(s), as gender is nothing but a physical difference.

Another important aspect of economic exploitation in the play happens when both $\mathrm{Ai}$ Leng and Mazuri, two common factory workers, are given orders to work at any time the employer pleases, as long as the latter (who are usually men) will benefit from the profit-reaping. At the same time, Lee satirises the typical foreigner employer's attitude towards his lower rank local employees, as Mr. Wu, the foreigner, shows little concern over his employees' welfare. He even mentions that it is not his obligation to provide transportation for his employees in the wee hours of the evening, but he will prepare 
one anyway just because. Mr. Wu represents the view of men who are looking at women's safety as secondary - he agrees to provide the aforesaid bus in order to ensure that his profits will double once the new shift is implemented. Even $\mathrm{Ma}$ is suspicious of Mr. Wu's intention and sincerity; Ma sees this newly-implemented shift as a way of labour exploitation, which is parallel to the era of British colonial period where poorly paid labourers were forced to work on the tin mines and rubber plantations. Ma's stance about this exploitation reflects the qualm of true independence, a situation that women are still facing until today.

In this play, 'patriarchal organisation' is criticised from several perspectives. First, the play is critical of 'The Centre', which further displays the strong relation between feminism and post-colonial theory. Even after achieving independence, many people still believe that Westerners do enjoy debasing people whom they once ruled. Frank, one of the organisers, is portrayed as a rather arrogant and abrasive, as well as critical of locals; in this case, Frank represents The Centre/the patriarch. In addition, one of the legacies left behind by British colonialism is the 'divide and rule' status quo. As a result, prejudices linger around the many races in this country.

$K L-K O$ continues its criticism towards 'The Centre' by highlighting this issue; one of the obvious examples regarding this matter is the loudmouth $\mathrm{Ma}$, who constantly continues to slip in a couple or two racial remarks in her dialogues, like her disappointment that Ai Leng spends more time at a Malay household and the fact that Nenek is a Chinese who converted into Islam, thus lost her "Chinese-ness" to the Malay community. Ma is also critical of the Malays, as she believes the aforesaid ethnic group are lazy, prejudiced towards other ethnicities and exploiting their preferential treatment in their daily lives.

Ai Leng efficaciously rebuts Ma's racist remarks in the end; this proves the earlier sentiment that younger generation is more open in interracial relations. It is vital to stress that as an original Malaysian play, $K L-K O$ has played a major role in injecting the aura of harmony to foster better understanding between human beings; this play portrays positive interracial interactions. Lee successfully portrays positive relations between a Chinese and Malay (Ai Leng and Mazuri), a scenario that does happen in our real life. This substantiates that women, regardless of their background (ethnic, religion or social status), interact and communicate better due to the "woman-ness" qualities. It also shows that the younger generation is better in bridging the cultural gap as compared to the predecessors, and this scenario puts forward a slap in the 
face to the former colonial powers; this validates the assumption that cultural feminism supports harmonious values in life, unlike the former colonial powers (presuming the role of 'the patriarch') who introduced the 'divide and rule' policy in this country.

\section{CONCLUSION}

The issues that have been obtained from KL-KO, which was written 20 years ago, were and are still relevant today. Women around the world are still contending to rout their naysayers and detractors in order to gain a toehold or to carve their own history. Sexual harassment is still major issue for women within workforce; the latest being Hollywood mogul Harvey Weinstein's disgraceful behaviour towards young starlets who were in his movies. Simultaneously, women continue to voice out criticism towards the patriarchy system that may adversely affecting them. However, the nurturing and caretaking roles of mothering (while having another career) are still in practice around the world. Even though feminism is always related to the ideas of going against the stream of nature, as believed by the patriarchal-led society, its influence in improving the livelihood of women around the world are still relevant. It is important to stress here that feminism as a political, social, intellectual, philosophical and artistic body of thought had introduced a way of putting in women's perspectives and of reminding how gender is a construction. In a recent interview with Ann Lee, she strongly believes that issues highlighted in KL-KO such as racism, stereotyped images of femininity and women's roles, sexual harassment, ageism, religious intolerance and lack of understanding, the contradiction between nationalism and patriotism, and capitalist profiteering are still relevant in our world today. She reveals that religion is in the background of $\mathrm{KL}-\mathrm{KO}$; a more deep-seated yet ordinary, everyday respect and practice that contrasts with a lot of the 'religiosity' of today. Moreover, Lee adds that everyday kind of religious expression is still relevant today, even though sometimes it looks so old-fashioned and can get swept away or dismissed under 'jahiliyyah' (A. Lee, personal communication, May 31, 2018).

At the final scene of the play, during the match between Ai Leng and Mike Tyson, $\mathrm{Pa}$, Ma, Pak Cik, Nenek and Mazuri joined the audience cheering for Ai Leng, as if a real boxing match that was taking place in the Experimental Theatre. KL-KO successfully instils itself as one of the grandest feminist plays during the finale. The arena stage allows the audience to sit around the stage, thus gave them ample space to participate in the final boxing match between Tan Ai Leng and Mike Tyson. When Mazuri joins Ai Leng at the end of the play, the former lifts the latter's arm as to celebrate the victory over tribulation and bigotry toward women. 


\section{REFERENCES}

1. Aston, E. (1999). Feminist theatre practice: a handbook. London: Routledge.

2. Austin, G. (1990). Feminist theories for dramatic criticism. Michigan: The University of Michigan Press.

3. Canning, C. (1996). Feminist theatre in the USA. London: Routledge.

4. Chow, E. (1996, October 13). Feminism sans ferocity. Sunday Mail, pp. 38.

5. Gillespie, P. (1978). Feminist theatre: A rhetorical phenomenon. Quarterly Journal of Speech. 64, 284-294.

6. Kantor, J. \& Twohey, M. (2017, October 5). Harvey Weinstein paid off sexual harassment accusers for decades. New York Times.

7. Keyssar, H. (1984). Feminist theatre: An introduction to plays of contemporary British and American women. London: Macmillan Publishers Ltd.

8. Lee, A. (1996). Kuala Lumpur knock-out. Kuala Lumpur: Kuali Works Sdn. Bhd.

9. Lee, A. (Director). (1996). Kuala Lumpur knock-out [Video recording]. Malaysia: Kuali Works.

10. Lee, A. (1996, July 4). Tolerance important to Ann Lee. New Straits Times.

11. Lee, A. (2012). Sex, stage \& state: Kuali Works plays. Jakarta: Parama Adhi Perkasa.

12. Scholz, S. (2010). Feminism. London: Oneworld Publications.

13. Shipp, E. (1992, March 27). Tyson gets 6-year prison term for rape conviction in Indiana. New York Times.

14. Tong, R. (2000). Cultural feminism. Encyclopedia of feminist theory. London: Routledge. 